\title{
EXTERNAL ECONOMIC EFFECTS OF AIR TRANSPORT DEVELOPMENT DUE TO THE LIBERALIZATION
}

\author{
Oksana Ovsak*, Maryna Vysotska \\ Department of Management of Enterprises Foreign Economic Activity, Faculty of Transport, Management \\ and Logistics, National Aviation University, Kyiv, Ukraine
}

*E-mail of corresponding author: ovsak@i.ua

\section{Resume}

The paper is devoted to research of the impact of gradual liberalization of aviation market on the country's air transport industry development and on formation of external economic components of the country's GDP connected to it directly: export and import of air transport services. The study of the relationship between the operation indicators of air transport and formed external economic effects has been conducted using comparative, correlative and regression analysis based on the statistical data of Ukraine, which has its own air transport industry and is on the path of aviation liberalization. A strong dependence of the export of air transport services on the total number of international flights and its passengers was revealed. This determines the feasibility of tracking the external economic effects in the design of changes on directions and means of further development of country's air transport sector.

\section{Article info}

Received 30 July 2020

Accepted 17 December 2020

Online 30 April 2021

\section{Keywords:}

aviation transport, liberalization,

export, import, GDP, external economic effects, operation indicators of air transport

ISSN 1335-4205 (print version) ISSN 2585-7878 (online version)

Available online: https://doi.org/10.26552/com.C.2021.3.A158-A173

(SSN $2585-7878$ (online version)

\section{Introduction}

In the recent decades many studies have been conducted to explore the impact of the air transport industry on the world economy and the economic system of the country involved. Well-known world aviation organizations, such as the International Civil Aviation Organization (ICAO), the International Air Transport Association (IATA), the Air Transport Action Group (ATAG), the European Regional Science Association (ERSA) publish annual reports, hold world conferences to inform the world community about the state and problems of global air transport development, reveal the specifics of its activities in the regional and national context, assess its impact on the economy and make development forecasts [1-4]. Problems of the aviation services market development are also cared of by the World Trade Organization (WTO) [5].

As a mode of transport, air transport contributes to development of the local economy, which receives primary, secondary, tertiary and perpetual effects [6]. Activity of the air transport companies works to increase the GDP of the involved country due to direct, indirect, catalytic and induced impact [1-5]. At the same time, with the growth of the GDP, the demand for air transport services is growing as an important component of the tourism business [5-7]. Like other modes of transport, there is a relationship between the growth of air transport enterprises' activity and the country's GDP [1, 6, 8-11], as well as regions [12]. The methodology for estimation of the economic (income) and social (employment) impact of the air transport on the national economy was presented in the research of Dimitrios and Maria [7], where all the quantifications of the socioeconomic impacts on the data of the Greek economy have been made.

Liberalization of air transportation is a steady trend in the world's civil aviation. Liberalization of air transportation is the gradual expansion of the established norms of air traffic regulation in the Chicago Convention, which has been signed in 1944 and the creation of special aviation regimes, which were called "open skies" [5-6]. Creation of the EU single aviation market put an end to the system of air services agreements between EU Member States [13]. Other countries are liberalizing aviation market by progressive expanding the terms of bilateral agreements on existing bilateral air services agreements between countries. Such agreements determine whether airlines can freely set tariffs (whether approval by the other party is required), how many airlines can provide transportation services and carrying capacity (capacity of air transportation services, e.g. volumes, frequency of air transportation, types of aircraft).

Liberalization has led to substantial economic and traffic growth due to increased competition and efficiency gains in the airline industry and positive externalities to the overall economy [6, 9, 12, 14-16]. Gillen, et al. [17] 
have provided fundamental investigations and have developed a model that provides measures of distribution of the gains and losses across the consumers and airlines of each country involved in the bilateral air transport agreement. In liberalized markets, there is a significant increase in traffic due to lower airline tariffs with increased competition [7-8, 14-15, 18]. Liberalization allowed for greater choice and more competitive prices for the travelling public. It arises positive externalities to the overall economy by stimulation of growth and employment opportunities, trade promotion and better transport and logistics services [15]. However, these impacts are not uniform across countries. The high competition leads to a change in composition of airlines operating in the country's aviation market, especially for small countries, whose national airlines are not leaders in minimum costs. The financial performance of aviation companies directly depends on the volume characteristics of aviation traffic [19]. This situation leads to their shift from the market and dominance of the world low-cost leaders [14-15, 18, 20]. As it was stated at the ICAO World Aviation Forum in 2015, liberal environment has led to the sustainable development of international air transport [14]. An example is the rapid development of the low-cost carrier AirAsia Group Berhad (AAGB), which is a powerful transnationaly integrated structure. In particular, researchers in [12] have found that global GDP, regional GDP, regional GDP per capita and population growth are the most correlated factors for the economic development of AAGB.

Today, the issue of determining the impact of further liberalization on development of a certain national economy and its air transport industry remains unresolved. This is a research from the economical point of view and from the perspective of searching for effectiveness and the optimal decision making while aviation market liberalizing. The example given is the nation of Ukraine, which has its own air transport industry and is on the path of aviation liberalization.

\section{Liberalization of aviation market and air transport development of Ukraine}

Nowadays, the basis of agreements about air traffic between Ukraine and other countries are bilateral air service agreements (ASA). Aviation communication between Ukraine and EU is regulated based on the bilateral air service agreements (ASA) with all the member states and Horizontal Agreement with the European Commission on certain aspects of air services. The last one has been developed by European Commission as a model agreement that liberalizes air services between the EU and third countries, called „horizontal“ [13]. The EU also provides setting up open aviation areas (so called "open skies") with key partners to further liberalise certain markets on the bilateral basis by European Common Aviation Area (ECAA) agreement between the EU and third countries [21]. In essence, it is a „free trade area“ for aviation, in particular in matters of flight safety, passenger protection, air carrier liability, environmental protection, competition and state aid. A major step forward in the liberalisation of EU-US air traffic was marked with provisional application in March 2008 of the EU-US Air Transport Agreement. This agreement introduced new commercial freedoms for EU and US airlines and a unique framework for regulatory cooperation in the field of transatlantic aviation [22]. In Europe the first such agreements were concluded with the countries of the Western Balkans and Morocco in 2006. In 2010 similar agreements were signed with Georgia and Jordan. In June 2012 an agreement was signed with Moldova. In general, the ECAA agreements have been concluded with the EU, Albania, Bosnia and Herzegovina, the Republic of Macedonia, Montenegro, Serbia, Kosovo, Norway, Iceland, Liechtenstein, Switzerland, Morocco, Georgia, Israel, Jordan and Moldova. According to the ECAA agreement, the air carriers guided by the common law on licensing and market access, competition, non-discrimination, flight safety and state aid have the right to operate within the EU. After signing such an agreement, the countries incorporate the EU norms into their national legislation in the field of air transport management. According to the ECAA Agreement, the air carriers have the right to operate within the EU guided by the common law on licensing and market access, competition, nondiscrimination, flight safety, state aid. After signing such an agreement countries incorporate the EU norms into their national legislation in the field of air transport management [21]. The Agreement with Ukraine was also based on the "horizontal" agreement, but it has been later expanded due to the presence of a large-scale aviation industry in Ukraine. Negotiations on signing the Agreement lasted from 2007 to 2013. The initialing of the ECAA agreement took a place on November 28, 2013 at the Ukraine-EU Summit in Vilnius. However, the signing of the Agreement has not taken place so far. The ASAs, as the main basis of regulation about air traffic between Ukraine and EU, designate airlines that are granted the right to operate flights on all the routes between countries. At present, Ukraine has concluded 70 ASAs on scheduled air services, 26 of which have been concluded between Ukraine and EU member states. Before 2002 such ASA had made the designation of airlines which are owned and controlled by nationals of that signatory EU Member State. However, in November 2002, the Court of Justice of the European Union (CJEU) found that such designation was discriminatory and was in breach of the EU law. Consequently, each EU Member State is required to grant equal market access for routes to destinations outside the EU to any EU carrier with an establishment in its territory [21]. Thus, the ASAs between the EU Member States and third countries, including Ukraine, have been amended to reflect this legal requirement. 

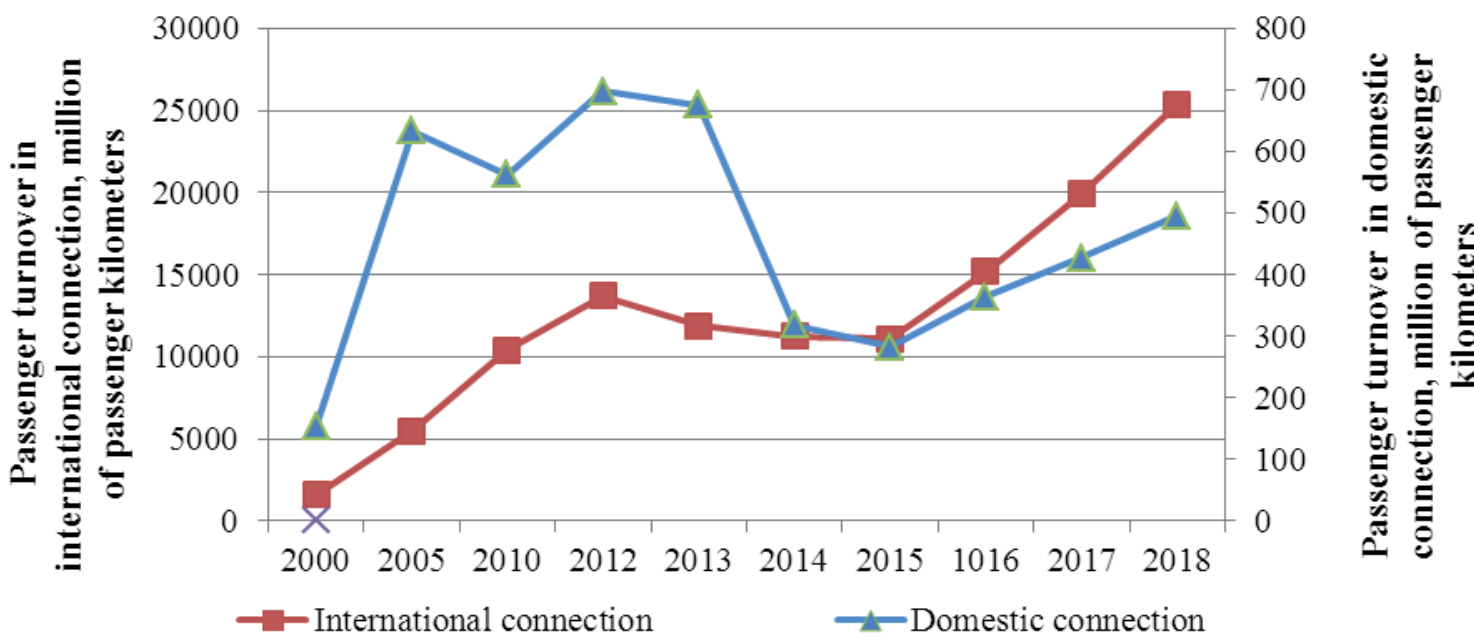

Figure 1 Passenger turnover of air transport of Ukraine by types of services, [24-25]

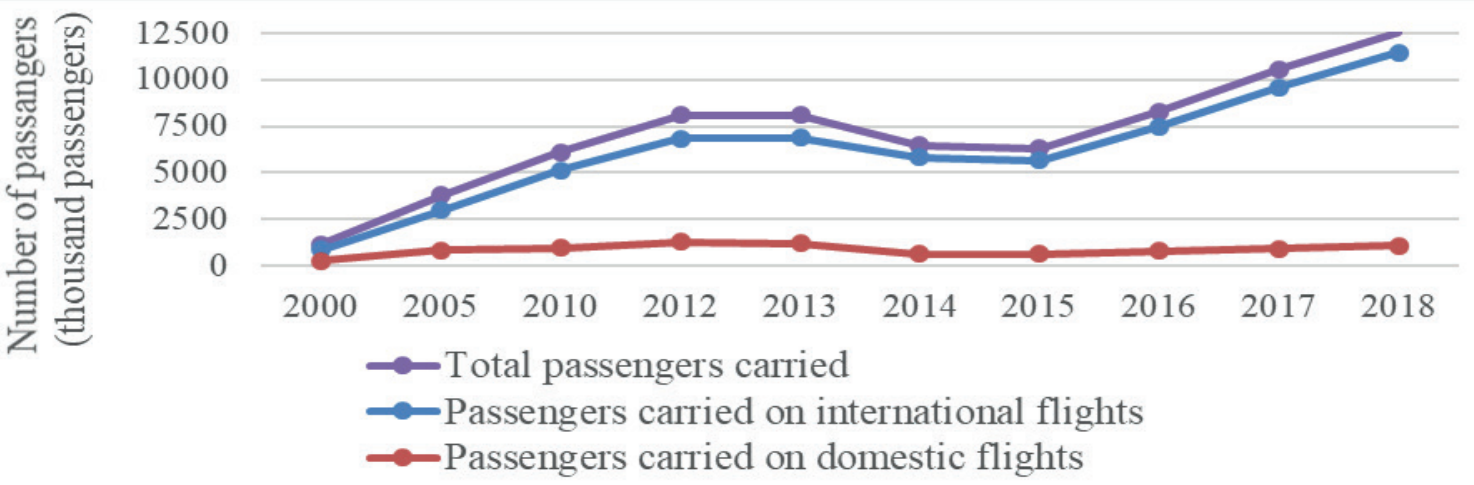

Figure 2 Dynamics of passenger transportation volumes by Ukrainian airlines, [24-25]

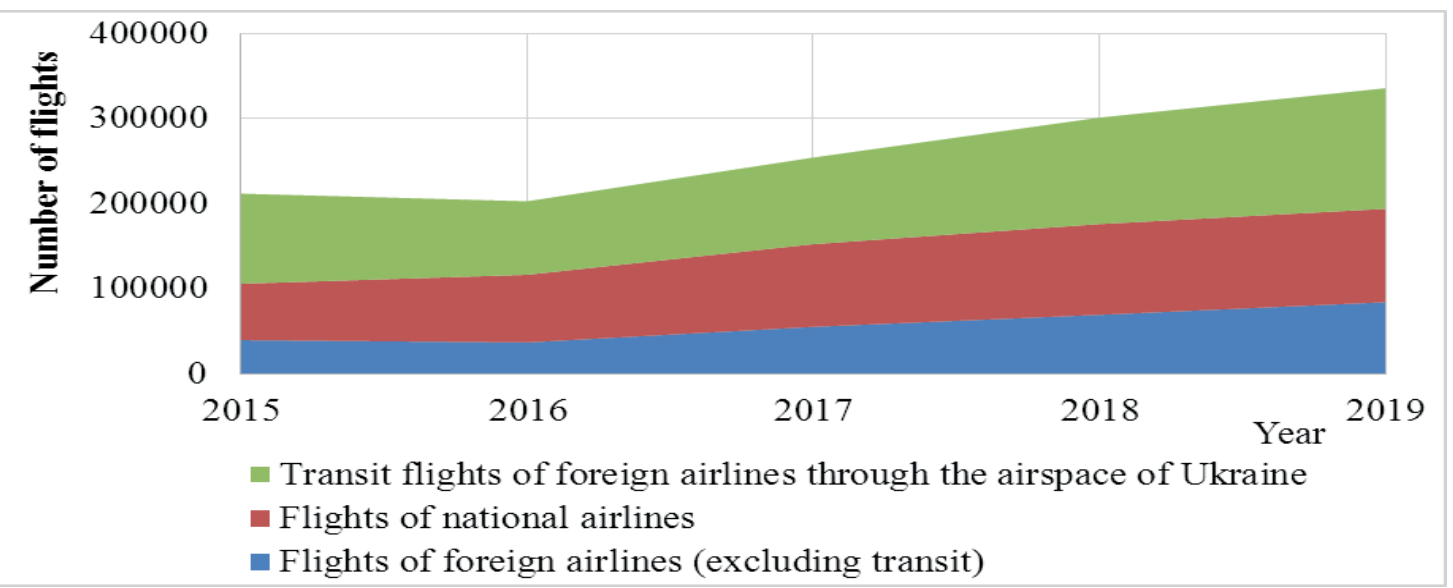

Figure 3 Flights of domestic and foreign airlines in the airspace of Ukraine between 2015 and 2019, based on [26, 30-32]

Thus, the low-cost companies, which were assigned to fly to Ukraine from the EU member states that did not have national airlines, were granted a wide access to Ukraine due to liberalization $[18,23]$. In the course of progressive liberalization in the ASAs, there was a gradual increase in the number of designated carriers and frequency of flights on international routes.

As of 2018, air transportation in Ukraine was carried out by 34 national airlines, which performed 100.3 thousand commercial flights, which was $7.8 \%$ higher than in 2017, with an annual increase by $18.7 \%$ in the number of passengers and international passenger traffic by $27 \%$. As shown in Figure 1, in 2016 there has been a $36 \%$ increase in international passenger traffic for the first time since the decline in 2013 due to the bankruptcy of the national airline - the monopolist "Aerosvit" and the redistribution of rights to international routes. In 2017 passenger turnover increased by $31 \%$.

Since 2015, after the decline, the number of 


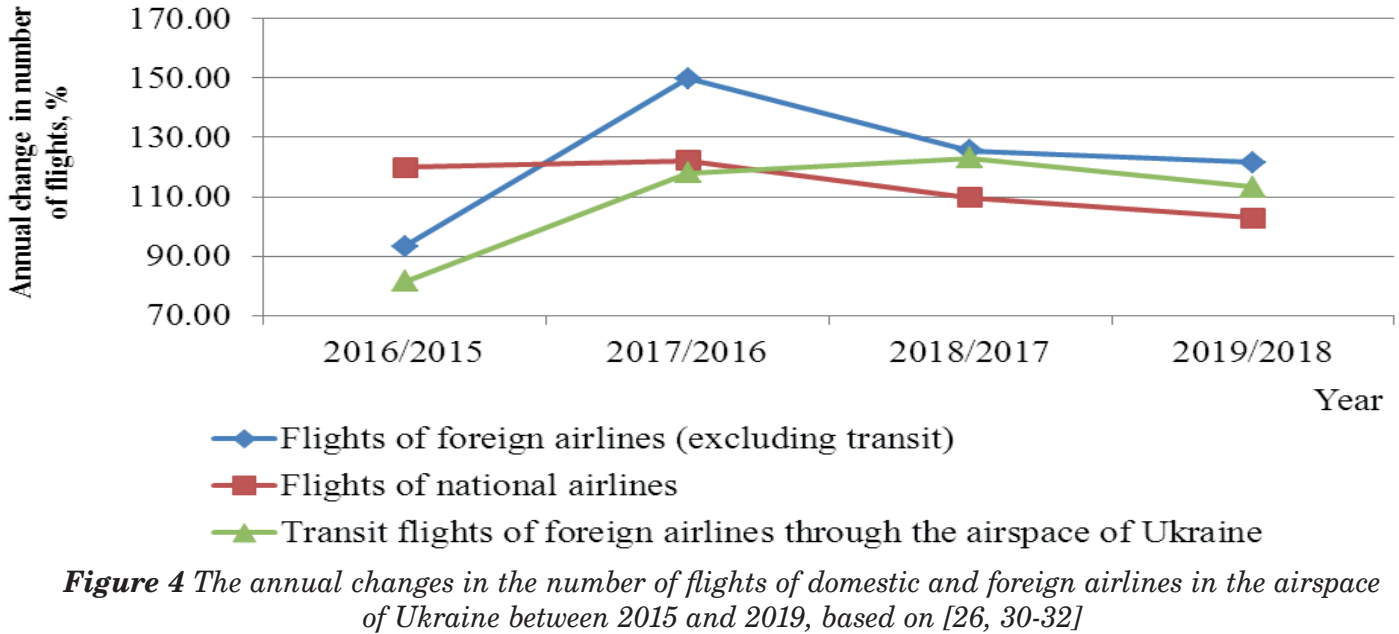

passengers carried on international flights of national airlines (scheduled and charter flights) has grown significantly: in 2016 by $31.6 \%$, in 2017 by $28.6 \%$ and in 2018 the growth slowed down to $19.5 \%$, as shown in Figure 2.

As of 2018 , more than the half $(54.2 \%)$ of all the passenger traffic of domestic airlines are international scheduled services. They were operated by 10 national airlines to 46 countries and the number of passengers who used their services increased by $16.4 \%$ and amounted to 6796.2 thousand people [26-27]. Moreover three of the national airlines, namely "Ukraine International Airlines", "Wind rose" and "Dniproavia", are parts of a strategic alliance based on joint ownership, which allows to improve the level of services in operational activities by providing aircraft in use, assigning slots at airports, providing convenient connections of routes [28]. As it was estimated by Oleshko and Heiets [29], the share of Ukraine in the global volume of aviation passenger traffic is not significant, but "despite the instability of the military, political and economic situation in the state, the growth rate of air traffic in the Ukrainian segment of the global aviation market is optimistic for predicting the future development of air transportation in Ukraine" [29, p. 5]. This is confirmed by analysis of changes in the number of flights of domestic and foreign airlines in the airspace of Ukraine between 2015 and 2019 as well as their annual rates (Figure 3, 4), performed in this article.

Thus, as shown in Figures 3 and 4, since 2016 there has been a positive trend of increasing the number of flights of both domestic and foreign airlines, as well as the number of transit flights of the latter. Since 2016, there has been a gradual slowdown in the growth rate of domestic airlines. At the same time, the growth rate of the number of flights of foreign airlines in the airspace of Ukraine slowed down slightly over the next two years after a rapid growth in 2017 by almost $50 \%$. Due to liberalization and expansion of bilateral interstate agreements on air services between Ukraine and other countries, in 2019 the number of flights of foreign airlines in the airspace of Ukraine increased by $21.5 \%$, while national airlines - only by $3 \%$ [31].

The observed trends indicate a significant development of the air transportation market due to the growth of activity of both Ukrainian airlines and foreign ones, which positively affects the business activity of Ukrainian airports. Thus, in January 2020 passenger traffic through the airports of Ukraine increased by $15.3 \%$ including international traffic with almost $17 \%$ compared to January 2019 [31].

To assess the level of aviation market liberalization, the Secretariat of the WTO has proposed the use of the Air Liberalization Index - (ALI), which is calculated based on the terms of bilateral air services agreements between countries [5]. At the beginning of 2017 the highest value of ALI calculated under the agreements of Ukraine with 54 other countries was at the level of 27, which corresponded to the average level [33]. By the end of 2019 the State Aviation Service of Ukraine decided to expand the conditions of operation of airlines under bilateral agreements, which governed air services of Ukraine with other countries, in particular, to increase the number of designated carriers and frequencies [34].

Since the liberalization of Ukraine's aviation market is not inherently a goal, but mostly a tool of ensuring Ukraine's integration into European airspace, there is a need to investigate its impact on Ukraine's economy through the study of the macroeconomic effects, namely the external economic effects of air transport development due to the liberalization.

\section{Methodology for external economic effects of air transport development assessment}

\subsection{Analysis background and definitions}

In general, the main effect on society from negotiated changes in bilateral air transport agreements or their removal is in providing more choices to air travel in terms of quantity, quality and fares, giving access to 
the most efficient airlines to liberalized air transport market. This effect ensures the growth of air traffic and due to the direct, indirect, induced and catalytic effects it influences the economies of countries that have implemented the air transport liberalization. Thus, the direct impact of air transport is manifested in the direct creation of working places in airlines and airports, in handling companies that provide ground maintenance of aircraft and passengers in airport terminals and in the provision of air navigation services. In creation of jobs to ensure the production of goods needed to serve passengers on board and aircraft at the airport (food, service), in other words, there is an indirect economic impact of air transport in related industries. The induced impact is realized due to the ability of air transport to generate additional demand for jobs in other sectors of the economy, such as consumer goods companies, retail stores, restaurants, financial insurance institutions, i.e. due to the multiplier effect. The catalytic influence of the air transport is realized in its ability to facilitate the interaction of economic agents in implementation of business processes, ensuring development of the non-related businesses. The air transport has such impact on the travel business and international trade in particular. It is known that the direct, indirect, induced and catalytic effects of the air transport industry created approximately 65.5 million jobs worldwide in 2018 , for comparison, 29 million jobs had been created as of 2005 (the growth of $226 \%$ ) [2]. The global economic impact of aviation (direct, indirect, induced and catalytic) is estimated at 2.7 trillion US dollars by experts, which is equivalent to $3.6 \%$ of the world's gross domestic product (GDP), for comparison, such an impact amounted to 2.960 billion US dollars as of 2005, which accounted for $8 \%$ of the world's GDP and was equivalent to the total GDP of the United Kingdom [1-2, 4]. The ACARE study estimates that air transport contributes $2.6 \%$ of the EU GDP, as it was indicated in the Eurocontril report [35]. According to studies of the impact of the air transport on the EU economy, the overall economic effect through investment and underlying productivity have been more significant, increasing the GDP by $4 \%$ [35].

In turn, the GDP growth stimulates growth in demand for the air transport services [5-9, 12]. The methodology for assessing the air transport socioeconomic impact on national economy is presented in the detailed research in [7], where all the quantifications of the abovementioned effects have been made on the Greek economy' data. The studies on the impact of liberalization of the air transport on airline competition and air passenger traffic, on airports' development, on the economy of the territories adjacent to airports and on the regional economy, have also been conducted [5-6, 8-9, 14-18, 20]. The economic gains that US air transport receives from negotiated changes in bilateral agreements, or their removal, has been examined by Button and Taylor in [6], mainly focusing on the economic benefits in terms of employment generation.
While considering the overall economic effects from freer trade in the air transportation services they have underlined the existence of incremental economic costs and benefits resulting from the policy change, such as the following: changes in the tax revenues and expenditures, "trade exports and imports and the balance of trade, in employment objectives: number and quality of jobs, development of tourism and related industries cost of travel to the business and tourist client" [6, p. 7].

In this study was assumed that for the country's air transport market the first direct effect of liberalization is growth of the international aviation traffic due to lower tariffs with the growth of the aviation network routes, as a result of competitive positioning of airlines and airports. The activity of national airlines in providing international air transportation is related to the consumption and provision of services to both residents and non-residents of the country. It enters into contractual relations with foreign air navigation services, airports, handling companies, airlines, ticket agencies and travel agencies, as well as the country's air navigation service, it's domestic airports and handling companies (residents) provide auxiliary services to foreign airlines - non-residents as regulated by the The Manual on Statistics of International Trade in Services, items 3.95-3.105 [36]. Accordingly, results of the external economic activity of aviation enterprises of the country are reflected in the articles „exports and imports of air transport services“. Thus, values of exports and imports of the air transport services of the country can be considered as consequences of the external economic activity of its aviation enterprises. They represent the external economic effects that the country acquires from development of its air transport. Accordingly, the difference between the export and import of a country's air transport services (ATS) can be regarded as a net external economic effect from development of the country's air transport, the volume of which is a component of the country's net export' formation and therefore the GDP. In addition, the total trade in aviation services reflects the overall international economic business activity of aviation enterprises residents, involved in the provision of international air transportation. Changes in the structure of air traffic (in the volume of passenger air traffic, in the number and ratio of flights of national and foreign airlines) affect the value of exports and imports of the air transport services. Values of exports of the air transport services (ATS' exports) of the country are formed by aviation enterprises provided aviation transportation services (passenger, cargo and auxiliary services) for the nonresidents [36-38].

The methodological approach used in earlier studies of the impact of the development of air transport on the GDP of a country, region and the world, is based on assessment of number of jobs created by aviation enterprises and their contribution to GDP [1-4, 7-8]. The direct contribution to the GDP was calculated 
Table 1 Nomenclature of used abbreviations

\begin{tabular}{ll}
\hline abbreviation & term \\
\hline GDP & gross domestic product \\
ATS & air transport services \\
NA & national airlines \\
NA Pax & the number of international flights' passengers of national airlines \\
IF Pax & the total number of passengers on international flights \\
IF Pax DEP & the number of passengers departing from Ukrainian airports in international traffic \\
IF Pax ARR & number of passengers arriving to Ukrainian airports in international traffic \\
IFNA & number of international flights of national airlines \\
IFFA & number of international flights of foreign airlines \\
Total IF & total number of international flights to and from Ukrainian airports \\
\hline
\end{tabular}

Table 2 GDP (million US dollars) and international trade of air transport services of Ukraine (thousand US dollars), [39-41]

\begin{tabular}{lccccccccccc}
\hline indicator & 2008 & 2009 & 2010 & 2011 & 2012 & 2013 & 2014 & 2015 & 2016 & 2017 & 2018 \\
\hline GDP & 179992 & 117228 & 136419 & 163160 & 175781 & 183310 & 131805 & 90615 & 93270 & 112154 & 130832 \\
export of ATS & 1231100 & 1111100 & 1181900 & 1501100 & 1510700 & 1333178 & 1071263 & 853619 & 882840 & 1091775 & 1221611 \\
import of ATS & 542400 & 338800 & 447600 & 685982 & 641300 & 643550 & 431038 & 466938 & 357465 & 452397 & 695720 \\
\hline
\end{tabular}

Table 3 Passenger traffic at the airports of Ukraine, thousands of people, [24-25]

\begin{tabular}{lccccccccccc}
\hline indicator & 2008 & 2009 & 2010 & 2011 & 2012 & 2013 & 2014 & 2015 & 2016 & 2017 & 2018 \\
\hline IF Pax DEP & 4087.3 & 3534.0 & 4148.5 & 5050.8 & 5733.0 & 6356.4 & 4777.3 & 4718.2 & 5663.6 & 7318.5 & 9115.2 \\
IF Pax ARR & 4087.6 & 3534.3 & 4148.1 & 5050.2 & 5741.4 & 6344.3 & 4727.0 & 4703.1 & 5630.9 & 7272.6 & 9142.3 \\
\hline
\end{tabular}

Table 4 International transportation of passengers by air, thousands of people, [24-25]

\begin{tabular}{lccccccccccc}
\hline indicator & 2008 & 2009 & 2010 & 2011 & 2012 & 2013 & 2014 & 2015 & 2016 & 2017 & 2018 \\
\hline NA Pax & 4934.8 & 4135.9 & 5144.3 & 6328.5 & 6820.9 & 6900.3 & 5826.6 & 5679.6 & 7475.3 & 9614.5 & 11446.1 \\
IF Pax & 8174.9 & 7068.3 & 8263.7 & 10030.6 & 11474.4 & 12700.7 & 9504.3 & 9421.3 & 11294.5 & 14591.1 & 18257.5 \\
\hline
\end{tabular}

by multiplying the number of employees of aviation enterprises by their average wage (before tax). With this approach, the contribution of all the aviation transport to the socio-economic development of a country or region is assessed regardless of the sources of its formation, that is, regardless of the activity of which aviation entities, national or foreign, such indicators of socioeconomic development were achieved.

The purpose of the methodology approach used in this research is the footprint analysis of the air transport development due to liberalization in terms of external economic effects on the national economy. The presented concept of assessing the external economic effects of air transport development can be used in addition to the methods used by ICAO, IATA [1-4], Button and Taylor [6], Dimitrios et al. [8], for a more complete assessment of the impact of air transport on the country's economy. The methodology used here can also be applied to identify additional external economic effects from liberalization of the country's air transport, due to its complex relationship with other sectors of the economy. The presence, of not only direct, but other types of influence of the air transport as well, was mentioned above.
Authors here relied on open sources of air transport 'statistics on indicators of air traffic and volumes of international trade to conduct investigation of their impact on formation of the external economic effects of Ukraine air transport services development. The study of the air traffic impact on the export and import of the air transport services was carried out by correlation and regression analysis.

\section{Statistical data and methods of analysis}

Quantification of aviation transport external economic effects was conducted based on the statistical reporting of Ukraine, the standards of which for collection and accounting of statistical reporting, in particular in the field of transport, meet the international standards, including the EU [36-38]. Further in the article for some terms abbreviations are used, as presented in Table 1.

Table 2 presents the statistical information from open sources on the GDP and volumes of international trade in aviation transport services of Ukraine. Tables 3-5 reveal statistical data on indicators of operational 
Table 5 Number of international flights (IF) to and from airports of Ukraine (flights), [24-25]

\begin{tabular}{lccccccccccc}
\hline indicator & 2008 & 2009 & 2010 & 2011 & 2012 & 2013 & 2014 & 2015 & 2016 & 2017 & 2018 \\
\hline IFNA & 57000 & 49401 & 62361 & 70928 & 70187 & 68152 & 55973 & 50713 & 63396 & 75117 & 83027 \\
IFFA & 55261 & 52490 & 56712 & 60939 & 70170 & 71213 & 51548 & 43900 & 41804 & 54983 & 69054 \\
total IF & 112261 & 101891 & 119073 & 131867 & 140357 & 139365 & 107521 & 94613 & 105200 & 130100 & 152081 \\
\hline
\end{tabular}

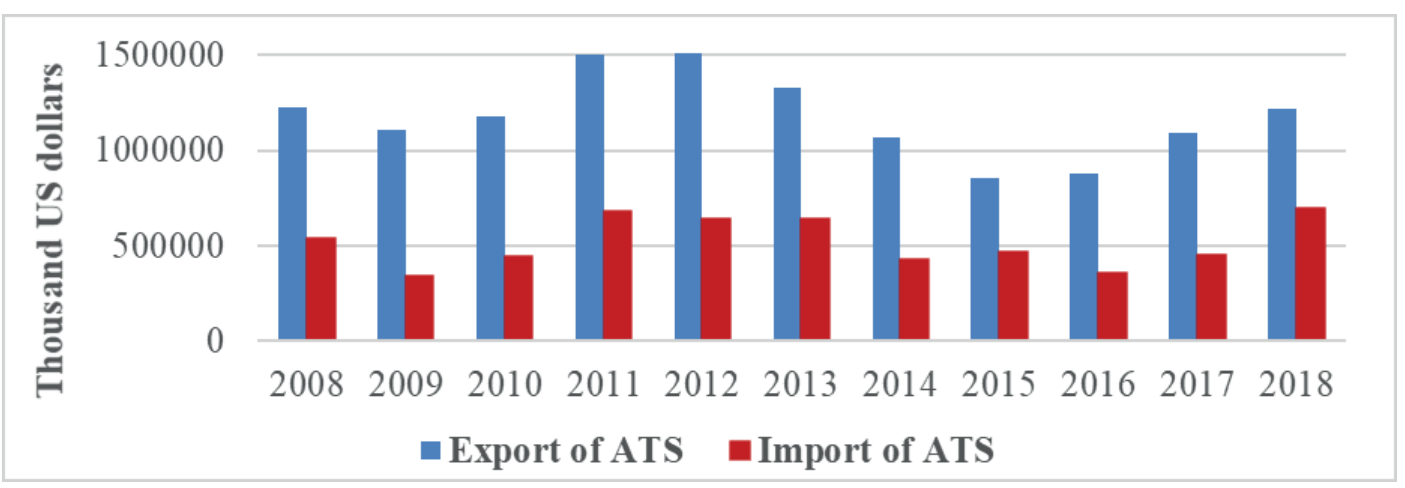

Figure 5 Dynamics of export and import of the air transport services of Ukraine from 2008 to 2018, based on Table 2

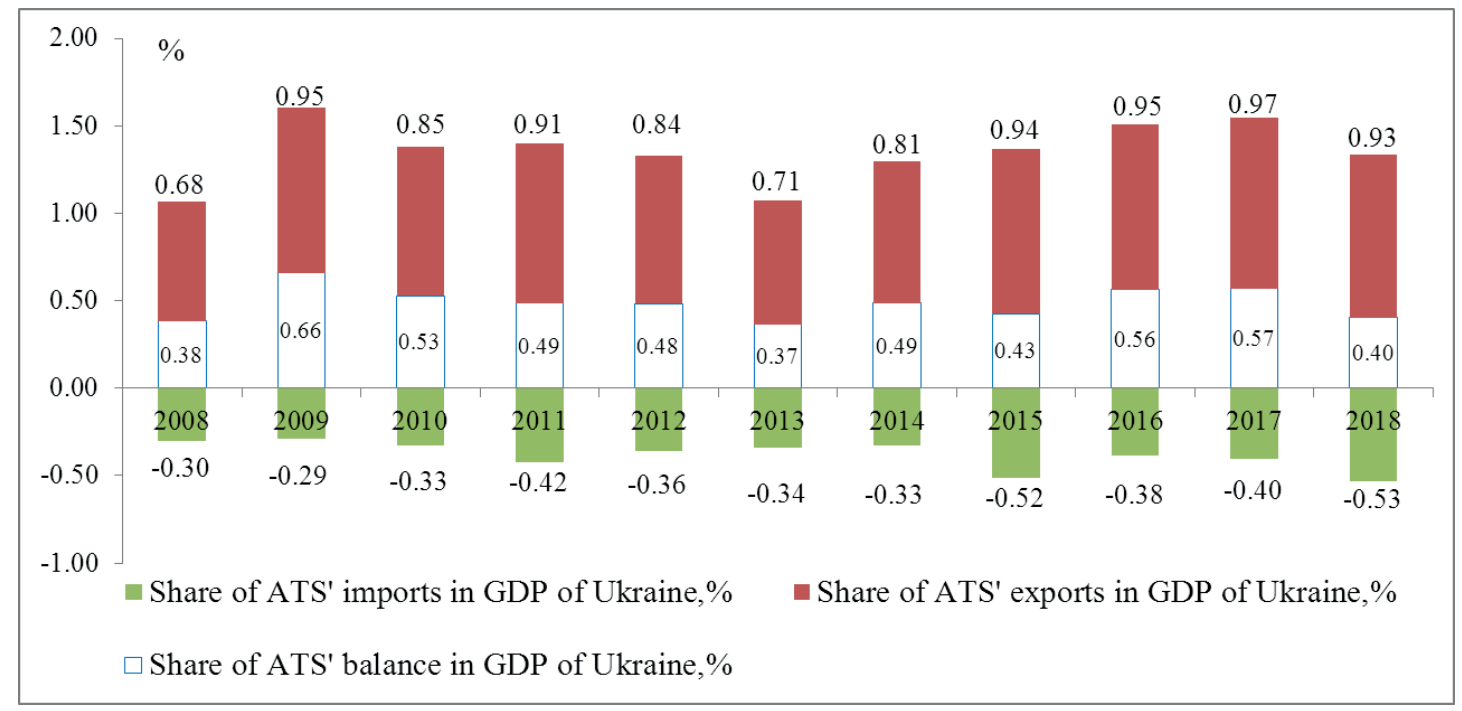

Figure 6 Value of shares of exports, imports and balance of the air transport services of Ukraine in GDP for the period 2008-2018, \%, based on Table 2

activity of the air transport of Ukraine for the period between 2008 and 2018, systematized from statistical reporting of Ukraine [24-25].

The IF Pax, the total number of passengers on international flights (both national and foreign airlines), was obtained by summing up the number of passengers arriving at Ukrainian airports and departing from them. In the context of research on relationship between the ATS' export (import) and operational indicators of the air transport, methods of regression and correlation were used. The correlation and regression analyses were for absolute and relative values of $x$ variables. The variables were chosen as follows: dependent (explained) variable $\mathrm{Y}$ as ATS' export (import) and independent (explanatory) variable $\mathrm{X}$ as operation indicator of the air transport: IFNA, IF, NA Pax, IF Pax. The correlation (r) and determination $\left(\mathrm{R}^{2}\right)$ coefficients were calculated using the Microsoft Excel software package. To determine the correlation strength, the following criteria were identified: strong dependence (if $0.8 \leq|\mathrm{r}|<1$ ), medium dependence (if $0.3 \leq|\mathrm{r}|<0.8$ ) and weak dependence (if $0<|\mathrm{r}|<0.3$.

\section{$5 \quad$ Results and discussions}

Figure 5 shows the dynamics of export and import of air transport services in Ukraine from 2008 to 2018, which formed the direct external economic effects of Ukraine's air transport, respectively, export represented a positive effect and import was a negative one in terms of impact on the total trade of air transport services of Ukraine.

Figure 6 presents values of shares of the exports, imports and balance of the air transport services of Ukraine in the GDP, for the period 2008-2018, 


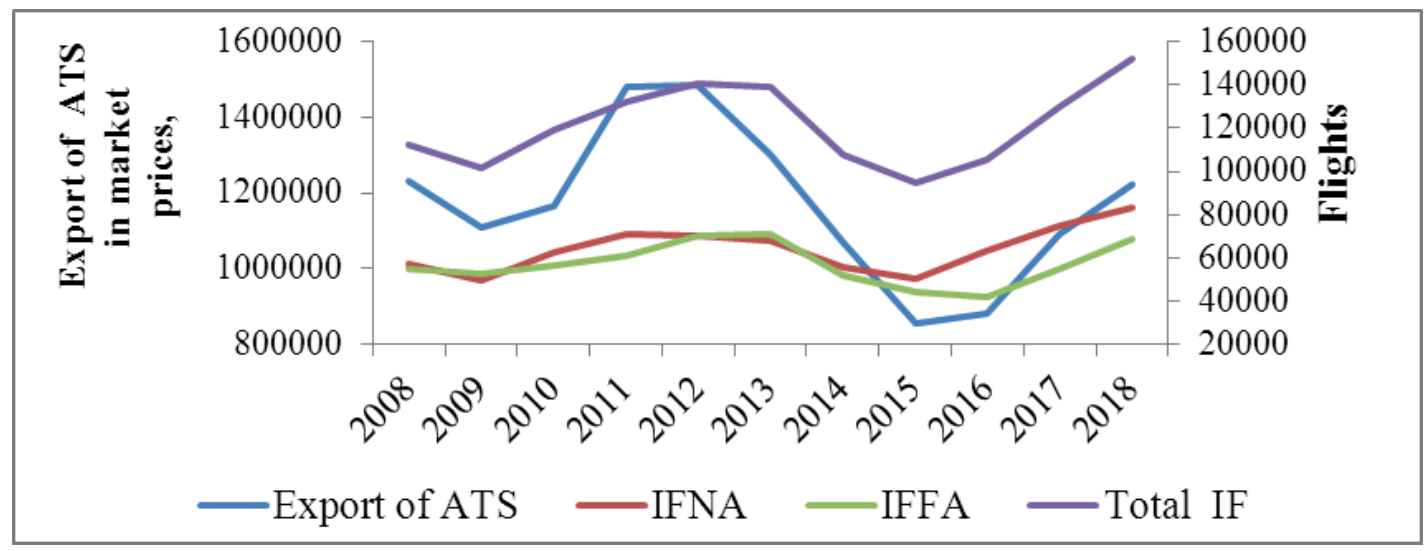

Figure 7 Relationship between the ATS' export and number of passengers on international flights of national, foreign airlines and the total number of passengers on international flights to and from Ukraine' airports for a period of 11 years, based on Tables 2 and 5

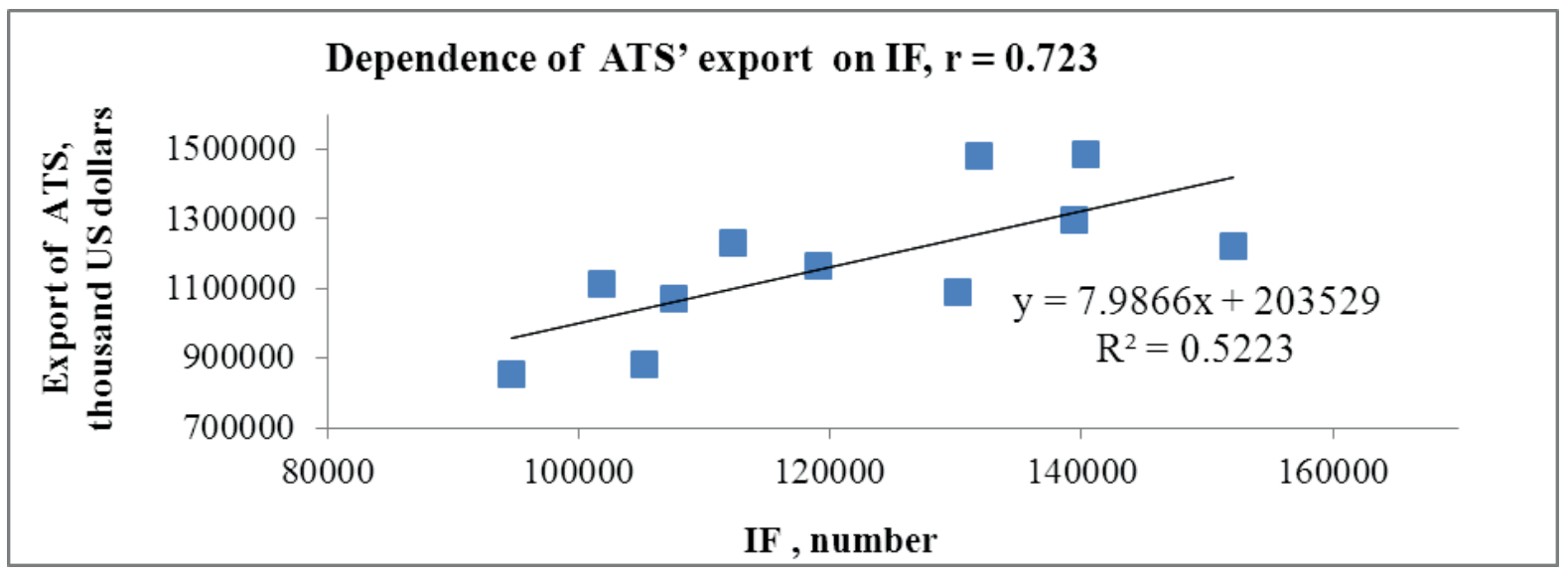

Figure 8 Dependence of the ATS' export on the total number of international flights to and from Ukraine' airports for a period of 11 years

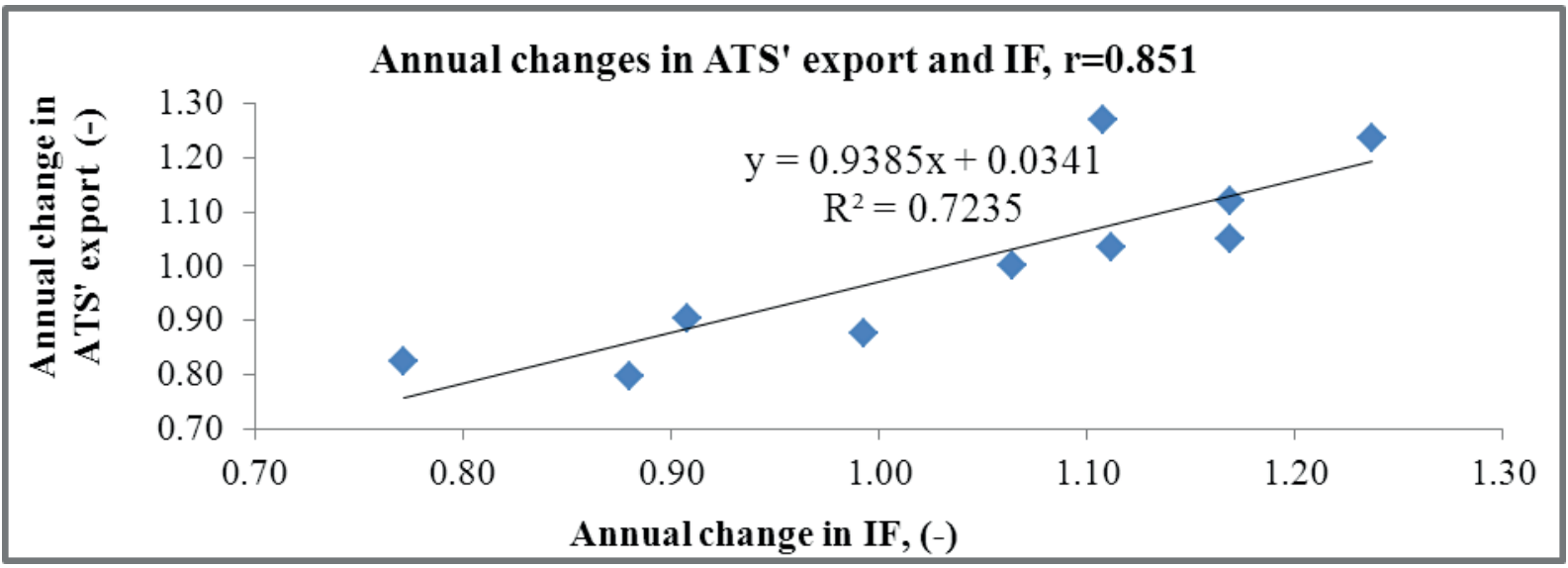

Figure 9 Dependence of the annual rates of changes in the ATS' export from annual rates of changes in number of international flights to and from Ukraine' airports

calculated based on Table 1. Thus, for 11 years of the study, the ATS' exports ranged between $0.68 \%$ of GDP and $0.97 \%$ of GDP and ATS'imports - between $0.3 \%$ of GDP to $0.53 \%$ of GDP. The balance of air transport services, respectively, ranged between 0.37 and $0.49 \%$ of Ukraine's GDP.

According to results of 2018, the IATA experts estimated that about $1.1 \%$ of Ukraine's GDP had been generated by the air transport and foreign tourists arriving by air [3]. In comparison to that value, the contribution of exports $(+0.93 \%)$ and imports (-0.53\%) to Ukraine's GDP was quite significant. The further study was focused on assessing the impact of the air transport volumes on formation of direct external economic effects.

The relationship between the dynamics of the ATS' exports and of the air traffic, represented by the number of international flights of national airlines (IFNA), foreign 


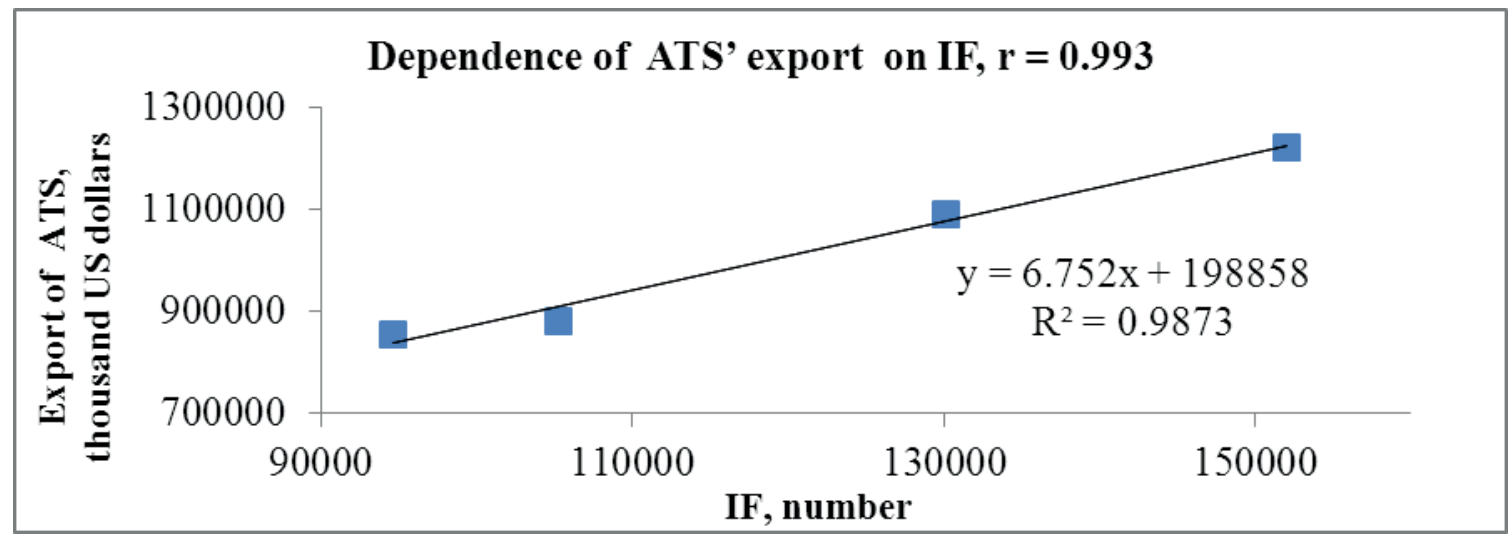

Figure 10 Dependence of the ATS' export on the total number of international flights to and from Ukraine' airports for the period 2015-2018

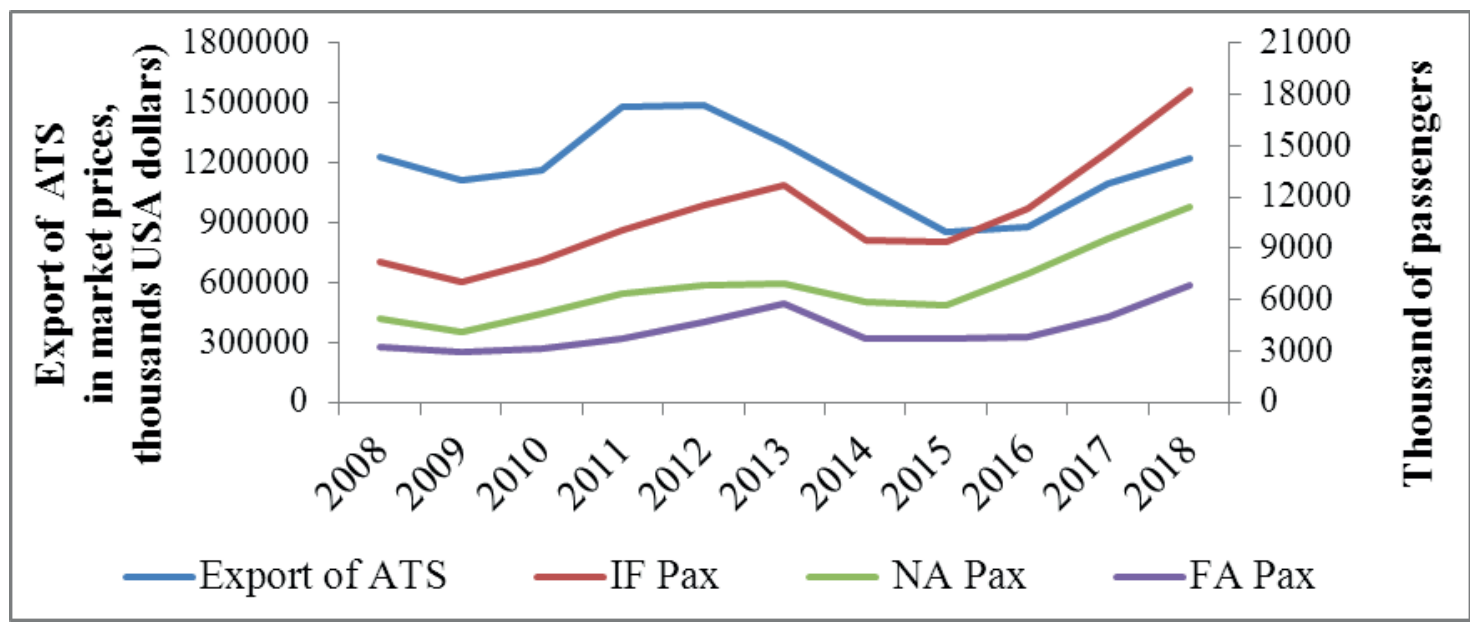

Source: Table 1, 3

Figure 11 Relationships between the ATS export and the number of passengers on international flights arriving at and departing from Ukrainian airports over the eleven-year period, based on Tables 2 and 4

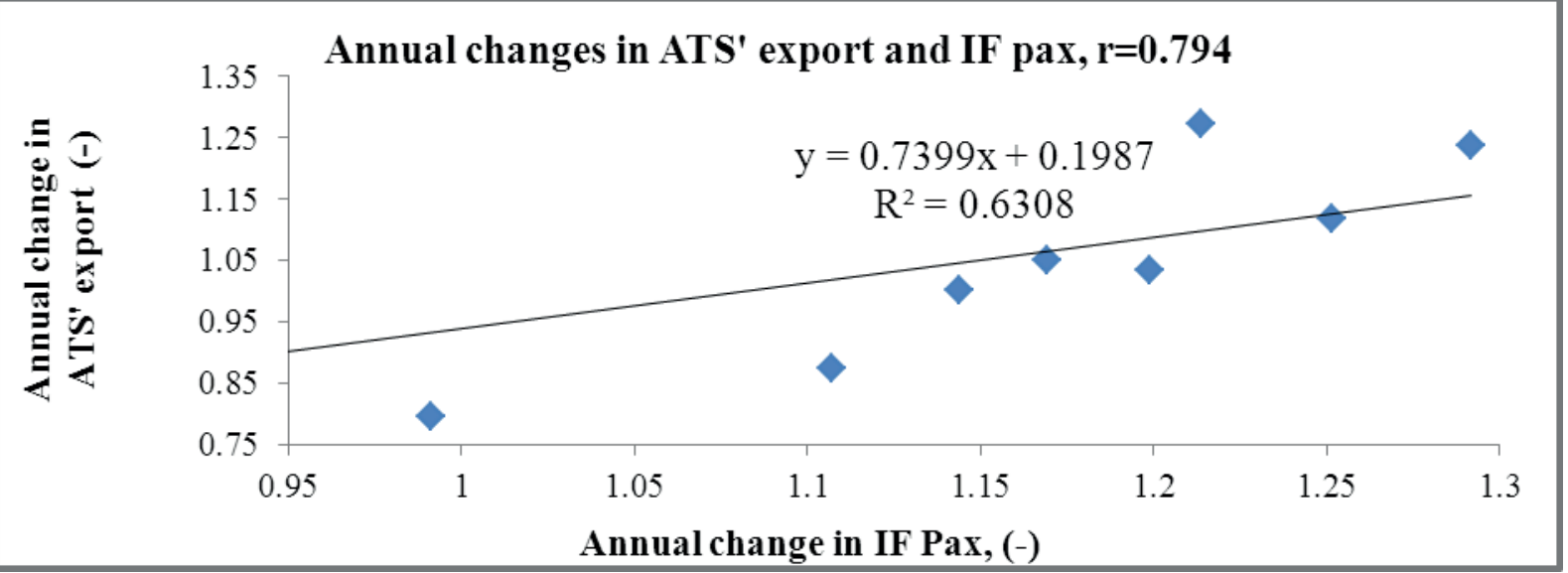

Figure 12 Relationship between annual changes in the ATS' export and total number of passengers of international flights (IF Pax)

airlines (IFFA) and the total number of international flights to and from the airports of Ukraine (Total IF) for a period of 11 years are clearly raced in Figure 7.

As can be seen from Figure 7 there was a positive relationship between the ATS export and the number of flights of both domestic and foreign airlines and the total number of international flights. In this study was used the total number of international flights. Results of the correlation analysis between the absolute values of the ATS' exports on the total number of international flights to and from Ukraine presented in Figure 8, had shown the presence of a sufficiently average dependence with the correlation coefficient $r=0.723$. However, the coefficient of determination $\mathrm{R}^{2}$ was equal to 0.52 , which indicated that the model built in Figure 8 was not statistically significant. 
Dependence of annual rates of changes in the ATS' export from annual rates of changes in the number of international flights to and from Ukraine' airports, considered as strong ( $r=0.845)$, which indicated the statistical significance of the variable IF. However, the coefficient of determination of the constructed trend $\mathrm{R}^{2}$ was equal to 0.43 , which indicated that the constructed model cannot be considered statistically significant, as presented in Figure 9. At the same time, for the data of four years of observations (2015-2018), correlated regression analysis of the dependence of ATS' exports on IF Pax, gave a correlation coefficient $r=0.993$ and determined Fisher's criterion $\mathrm{F}=77.5$, which was much higher than the corresponding tabular value, which indicated the statistical significance of the model presented in Figure 10.

Figure 11 presents a study of the relationship between export from the ATS and the number of passengers carried on international flights of national and foreign airlines and their total number of flights that began and ended at Ukrainian airports, excluding the direct transit passengers.

As can be seen from Figure 11, there were a positive relationships between the ATS export and the number of passengers on international flights of both domestic and foreign airlines and the total number of passengers on international flights. Results of the study of the relationship between the absolute values of the ATS' export and IF Pax, using correlation analylis showed very weak correlation $(r=0.119)$, while identified a strong relationship between the annual changes in their values $(r=0.794)$, as shown in Figure 12 .

That is, the IF Pax variable was statistically significant. However, for this case, the linear regression model is not statistically significant, due to the low value of the Fisher test $(F=1.7)$, which is less than the corresponding tabular value at the value of the significance level $\alpha=0.05$.

At the same time, for the data of four years of observations (2015-2018), correlation-regression analysis of the dependence of ATS'exports on IF Pax, gave a correlation coefficient $\mathrm{r}=0.987$ and determined Fisher's criterion $\mathrm{F}=29.1$, which was much higher than the corresponding tabular value (Figure 13). A similar regression-correlation analysis of the dependence of the annual change of ATS 'export on the annual change of IF Pax, based on observational data from 2015-2018, revealed a correlation coefficient $\mathrm{r}=0.998$ and Fisher's criterion $\mathrm{F}=38$ (Figure 14). These results showed the statistical significance of linear regression models for dependencies for 2015-2018.

Thus, the liberalization of the Ukrainian aviation

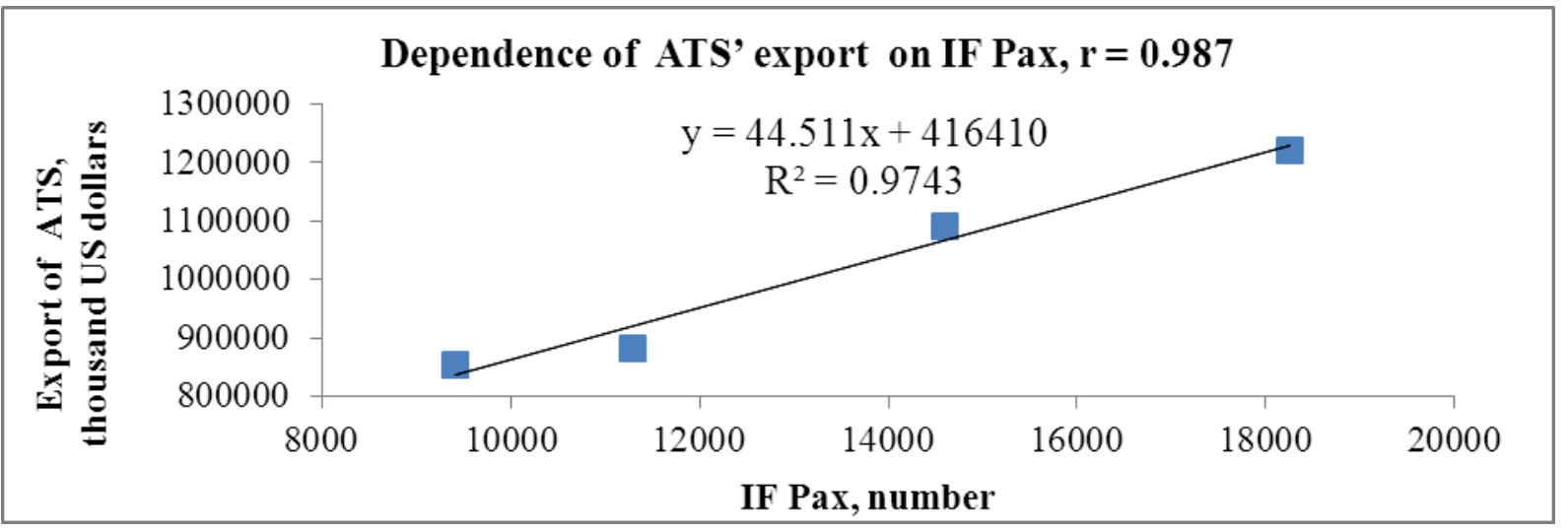

Figure 13 Relationship between the ATS' export and the total number of passengers on international flights (IF Pax) for a period 2015-2018

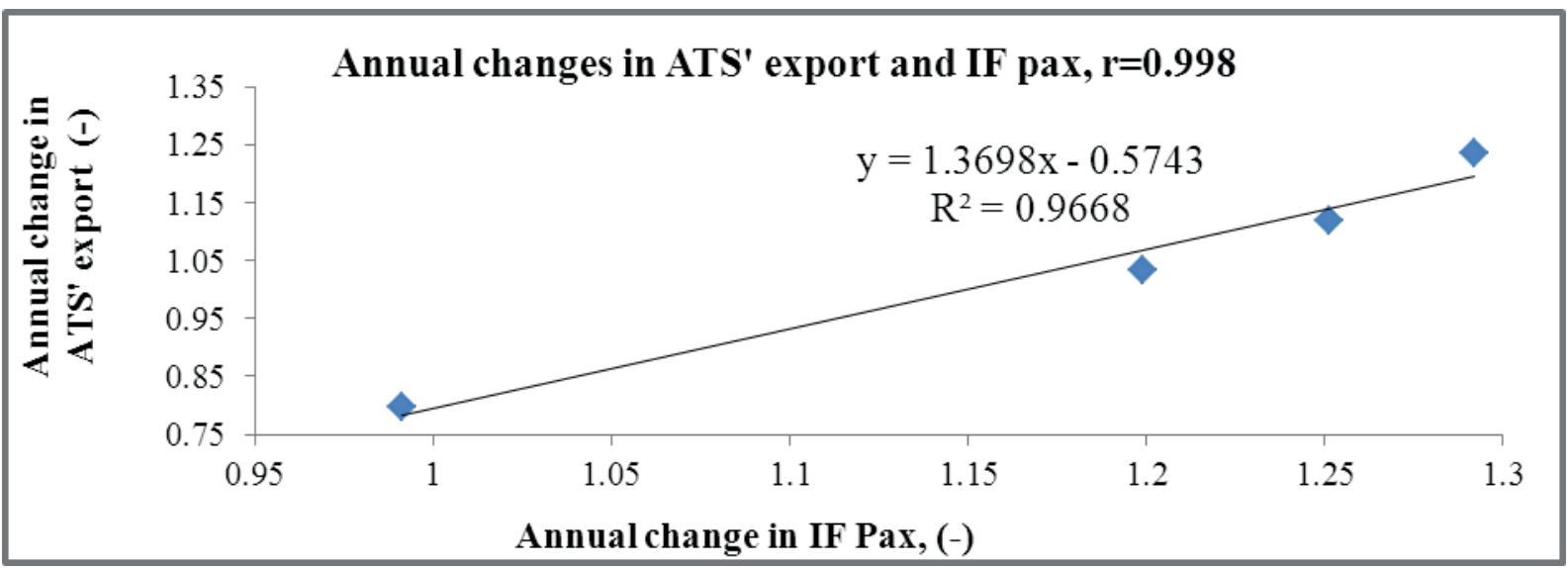

Figure 14 Relationship between annual changes in the ATS' export and total number of passengers of international flights (IF Pax) for the period 2015-2018 


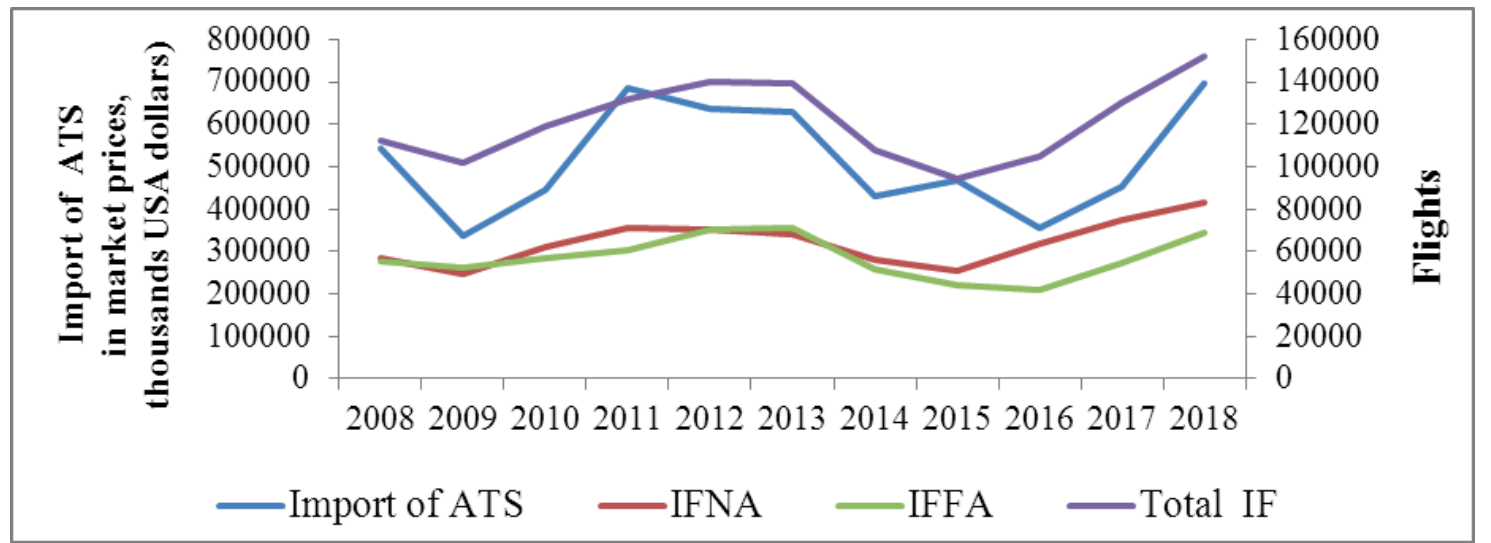

Figure 15 Import of air transport services (ATS) and the number of international flights of national airlines, foreign airlines and the total international flights to and from Ukraine' airports, based on Tables 2 and 5

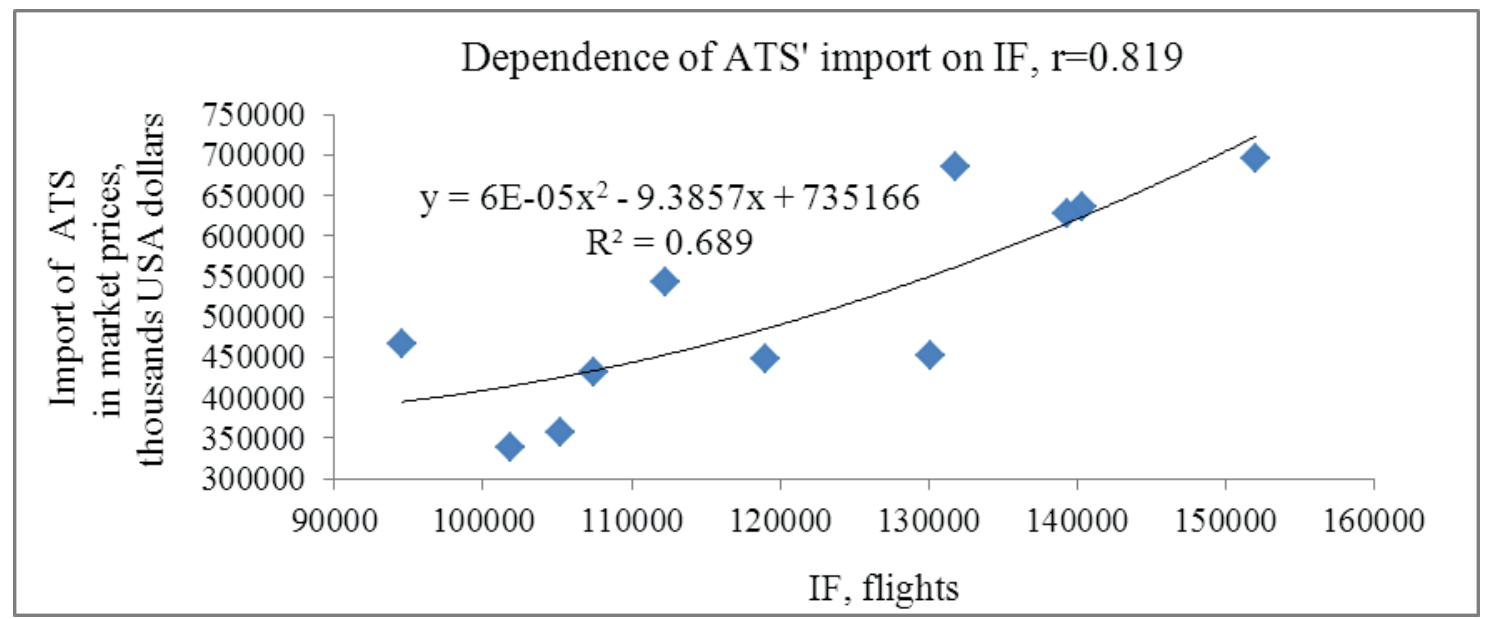

Figure 16 Dependence of the ATS' import on the total number of international flights to and from Ukraine' airports

market, which actually developed in the period 20152018, significantly increased the statistical significance of variables of the air traffic (number of international flights, their passengers, annual rate of change) for models of ATS'export. Therefore, to predict the value of the ATS exports and annual changes in ATS exports, one can focus on the constructed linear regression models shown in Figures 14 and 15.

As can be seen from the visual observation of Figure 15, there were a positive relationships between ATS' import and the number of flights of both national and foreign airlines and the total number of international flights.

As the simulation showed, a confident average dependence of the ATS' import on the total number of international flights has been revealed when both absolute and relative changes of indicators were analyzed. Dependence of the ATS' import on quantity of international flights to and from Ukraine' airports, can be considered as strong $(r=0.819)$. The coefficient of determination showed that for $69 \%$ of cases the value of ATS' exports was determined by function of the IF dependence, presented in Figure 16. Correlationregression modeling of this dependence, performed based on observations from 2015-2018, showed that the IF variable was statistically significant $(r=0.789)$ and the model was statistically significant $\left(R^{2}\right.$ was equal to 0.97 ), in $97 \%$ of cases, the import of the ATS was determined by the function presented in Figure 17.

Figure 18 presents a study of the relationship between the import from the ATS and the number of passengers on international flights of Ukrainian airlines, foreign airlines and the total number of international flights.

As can be seen from Figure 18, there was a positive relationship between the ATS import and the number of passengers on international flights of both domestic and foreign airlines and the total number of passengers on international flights. The correlation coefficients showed that there were the weak dependence of the ATS' import from the total number of passengers on international flights of national airlines and from the number of passengers on total international flights $(0.423$ and 0.512 ).

Results of the study of the relationship between annual rates of changes in the ATS' import and annual rates of changes in the total number of passengers on international flights of national airlines and annual rates of changes in the number of passengers on total international flights, showed average correlation $(\mathrm{r}=$ 0.703 and 0.717 ), while the accuracy of selection of the regression equations was about $50 \%$, which indicated 


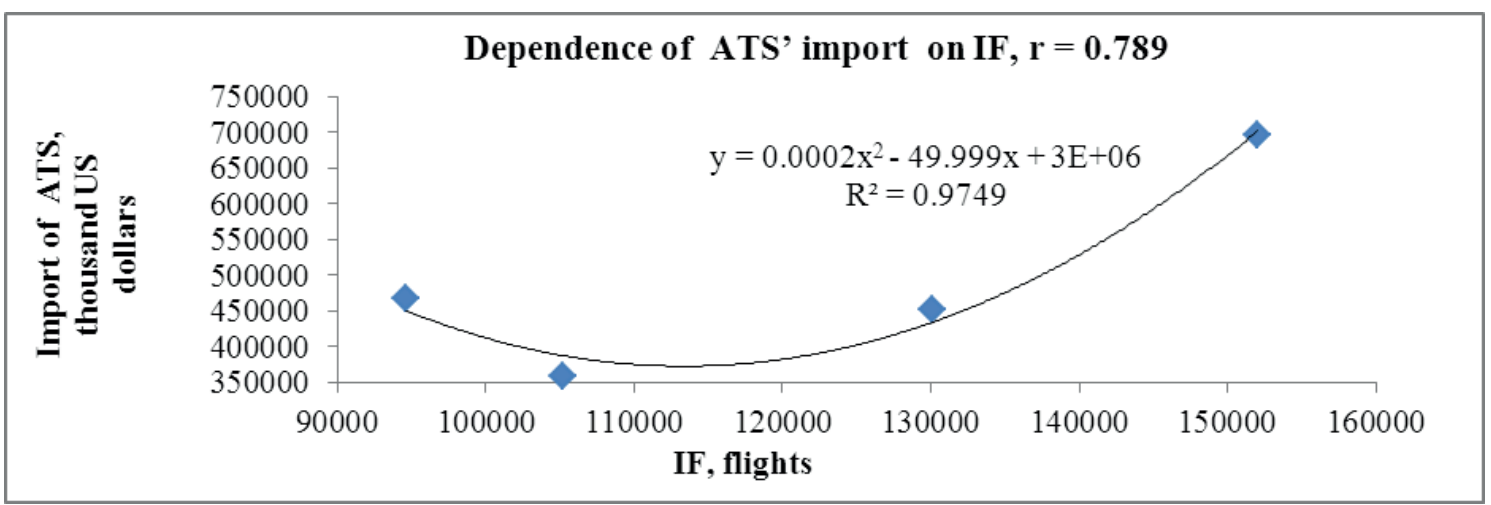

Figure 17 Dependence of the ATS' import on the total number of international flights to and from Ukraine' airports for 2015-2018

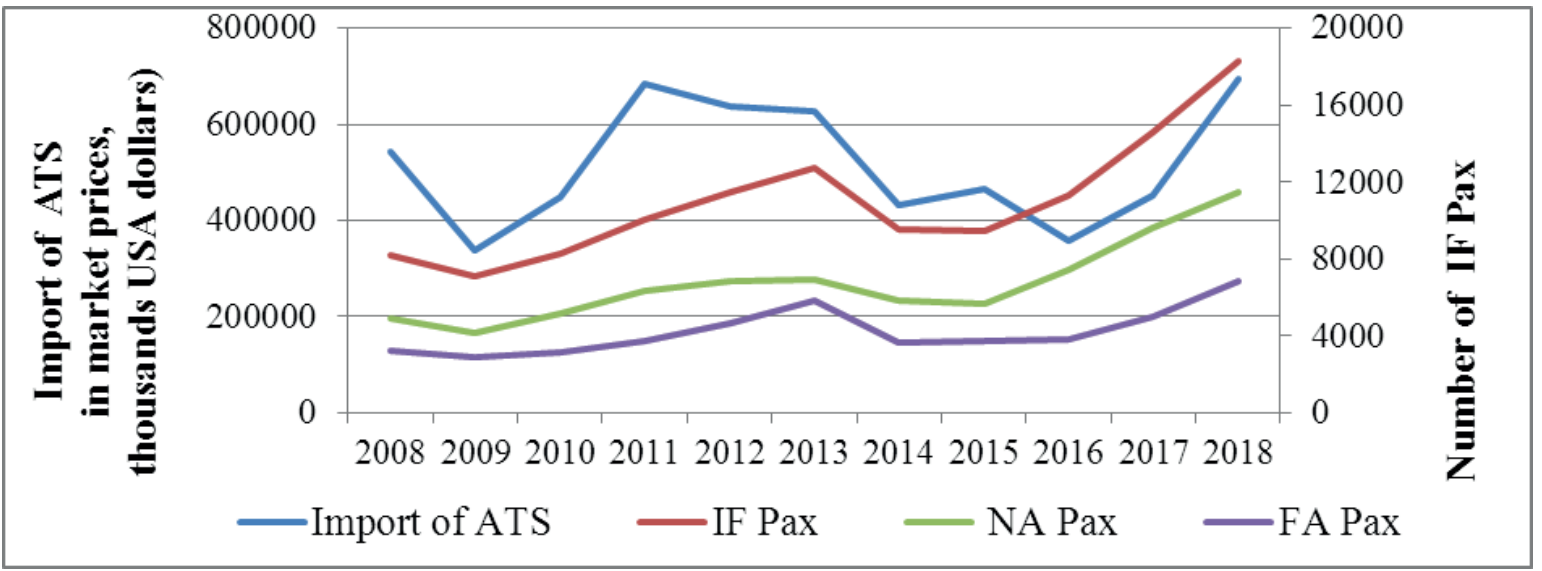

Figure 18 The relationship between import from ATS and the number of passengers on international flights, based on Tables 2 and 4

Table 6 Dependence of the ATS' import and ATS' export on IF, NA Pax, IF Pax

\begin{tabular}{cccc}
\hline & IF & NA Pax & IF Pax \\
\hline export of ATS & 0.723 & - & 0.119 \\
import of ATS & 0.818 & 0.423 & 0.512 \\
\hline
\end{tabular}

Table 7 Dependence of the annual rates of changes in the ATS' import and ATS' export on annual rates of changes in IF, NA Pax, IF Pax

\begin{tabular}{cccc}
\hline & IF & NA Pax & IF Pax \\
\hline export of ATS & 0.851 & - & 0.94 \\
import of ATS & 0.672 & 0.703 & 0.717 \\
\hline
\end{tabular}

that the model could not be considered statistically significant. The correlation-regression modeling, based on data for the period 2015-2018, showed similar results. The results of correlation analysis for a period of 11 years are presented in the Tables 6 and 7 .

Due to the significant difference between the absolute values of endogenous and exogenous variables, it was found that the correlation between some of them was more pronounced in the analysis of their annual rates of change. The analysis of the correlation coefficients between the annual growth rates of the ATS' exports and the indicators of air traffic revealed a strong dependence of the ATS' exports on number of passenger flights and passengers of such flights. The correlation between values of the ATS' imports and aviation traffic indicators was more pronounced in the analysis of their annual rates of change and can be assessed as a confident average. So, the main conclusion is that the gradual liberalization of the aviation market of Ukraine has led to an increase in the number of passenger flights and passengers on such flights, which directly affected the increase in export earnings from the air transport services.

To continue the discussion, it should be noted that the proposed methodological concept for assessment of external economic effects of the air transport development allows to understand the mechanism of its influence on the formation of national economy indicators much better, as well as to track the impact of air traffic 
due to the development of air transport, in particular, liberalization, on formation of the external economic effects of the national economy. The advantage of the proposed methodological approach is in availability of data for assessing the external economic effects, both direct and additional. The proposed concept for assessing the external economic effects of the development of air transport can be used for a more complete assessment of the impact of air transport on the country's economy as additional to the methods used by ICAO, IATA [1-4], Button and. Taylor [6] and Dimitrios et al. [8].

As the study showed, there has been a gradual increase in the magnitude of external economic effects due to introduction of the liberalization conditions in bilateral air services agreements between Ukraine and other countries since 2015. The analysis of the relationship between the external economic effects of Ukraine's air transport development and air traffic indicators revealed a strong dependence of positive external economic effects of the air transport development on the total number of international flights to and from Ukraine's airports. Similar results for airports were reported by researchers Button and Taylor [6], who, while studying a relatively large number of US airports, found that the international air transport stimulated additional growth of business activity and new jobs in the area adjacent to the airports.

Thus, according to results of the research confirmed that here was a significant positive relationship between the traffic volumes and liberalization of the aviation market, as it was indicated in $[6,8,14,15,17,18]$. The strong dependence of the positive external economic effects of the air transport development in Ukraine on the air traffic volume indicates the feasibility of further liberalization of the aviation market. At the same time, the additional study of factors and peculiarities of formation of import of the air transport services is required, taking into account its growth over the last year of the research. The limitations in conducting this research were associated with difficulty of obtaining the detailed data on activities of enterprises belonging to different statistical groups of the air transport industry (airlines, airports, handling companies, air navigation services). The identified relationships of the external economic effects of the air transport development from such parameters of air traffic as the number of international flights and the number of passengers of international flights, do not exclude influence of other indicators of the air transport operations, their relationship and aggregate action. Formation of magnitude of the ATS exports and imports is influenced by such variables as volume of air traffic (passenger and cargo flights, number of transported passengers and cargo), air traffic structure (domestic and foreign airlines), price level, tax burden, values of airport charges, the cost of slots, the level of aviation tariffs and other indicators that affect activities of aviation entities in a competitive environment.

\section{Conclusions}

The growth of the air traffic affects the GDP valueand contributes to development of the country's economy due to liberalization of the air transport taking into account its direct, indirect, induced and catalytic impact. Changes in the air traffic structure, which occur due to the redistribution of traffic between the domestic and foreign airlines, have an impact on the formation of export and import of air transport services in the country. One can determine the external economic effects that a country acquires from its liberalization, while observing the dynamics of components of the international trade in the air transport services, when changing the indicators of air traffic. The numerical example was Ukraine, which has its own air transport industry and is on the path of aviation liberalization. The prevalence of a direct positive external economic effects of the air transport development over a negative ones was revealed during the study period between 2008 and 2018. The value of the ATS' exports in recent years of research formed an average of $0.95 \%$ of Ukraine's GDP. The study has found that the gradual liberalization of the aviation market of Ukraine led to an increase in international traffic, which was directly reflected in the increase in the export earnings from air transport services. The strong dependence of the positive external economic effects of the air transport development in Ukraine on volume of the air traffic indicated the feasibility of further liberalization of the aviation market. The presented methodological approach on taking into account the external economic effects of the air transport development through further liberalization and the findings can be used by the country's aviation administration in developing the management decisions on the feasibility of structural changes in the air transport sector and areas for improving the transport policy, including aviation infrastructure.

\section{Acknowledgement}

This article is published within realization of the project UA No. 92/11.02.03 „Study of the export potential of the aviation complex of Ukraine" of the Department of Management of Enterprises' Foreign Economic Activity of the Faculty of Transport, Management and Logistics, National Aviation University.

\section{Author contributions}

Oksana Ovsak: conceptualization, methodology, data curation, investigation, visualization, writing original draft preparation, writing - reviewing and editing.

Maryna Vysotska: conceptualization, supervision, validation. 


\section{References}

[1] The economic and social benefits of air transport [online] [accessed 2020-02-03]. Available from: https://www. icao.int/Meetings/wrdss2011/Documents/JointWorkshop2005/ATAG_SocialBenefitsAirTransport.pdf

[2] Aviation benefits report 2019 [online] [accessed 2020-02-05]. Available from: https://www.icao.int/sustainability/ Documents/AVIATION-BENEFITS-2019-web.pdf

[3] The importance of air transport to Ukraine [online] [accessed 2020-01-15]. Available from: https://www.iata.org/ en/iata-repository/publications/economic-reports/ukraine--value-of-aviation

[4] Aviation: benefits beyond borders 2014 report - Air Transport Action Group, April 2014. [online] [accessed 2019-1223]. Available from: http://aviationbenefits.org/media/26786/ATAG__AviationBenefits2014_FULL_LowRes.pdf

[5] PIERMARTINI, R., ROUSOVA, L. Liberalization of air transport services and passenger traffic - 2008 WTO Staff Working Papers ERSD-2008-06, World Trade Organization (WTO), Economic Research and Statistics Division [online]. [accessed 2020-05-13]. Available from: https://www.wto.org/english/res_e/reser_e/ersd200806_e.pdf

[6] BUTTON, K. J.; TAYLOR, S. International air transportation and economic development. In: 40th Congress of the European Regional Science Association: „European Monetary Union and Regional Policy“: proceedings [online] [accessed 2020-05-12]. Louvain-la-Neuve: European Regional Science Association (ERSA). Available from: https://www.econstor.eu/bitstream/10419/114969/1/ERSA2000_483.pdf

[7] DIMITRIOS, D., MARIA, S. Assessing air transport socio-economic footprint. International Journal of Transportation Science and Technology [online]. 2018, 7, p. 283-290 [accessed 2020-02-17]. ISSN 2046-0430. Available from: https://doi.org/10.1016/j.ijtst.2018.07.001

[8] DIMITRIOS, D., MOURMOURIS, J., SARTZETAKI, M. Quantification of the air transport industry socioeconomic impact on regions heavily depended on tourism. Transportation Research Procedia [online]. 2017, 25, p. 5242-5254. ISSN 2352-1465. Available from: https://doi.org/10.1016/j.trpro.2018.02.051

[9] LAKSHMANAN, T. R., CHATTERJEE, L. R. Economic consequences of transport improvements. Journal of Transportation Research at the University of California. 2005, 26, p. 28-34. ISSN 2169-3536.

[10] CIGU, E, AGHEORGHIESEI, D. T., GAVRILUA (VATAMANU) A. F., TOADER, E. A. Transport infrastructure development, public performance and long-run economic growth: a case study for the EU-28 countries. Sustainability [online]. 2018, 11(1), p. 1-22 [accessed 2020-02-12]. eISSN 2071-1050. Available from: https://doi.org/10.3390/su11010067

[11] GNAP, J., KONECNY, V., VARJAN, P. Research on relationship between freight transport performance and GDP in Slovakia and EU countries. Preliminary communication. Nase More: International Journal of Maritime Science and Technology [online]. 2018, 65(1), p. 32-39 [accessed 2020-04-03]. ISSN 0469-6255, e-ISSN 1848-6320. Available from: https://doi.org/10.17818/NM/2018/1.5

[12] WU, C. Y., HEIETS, I., SHVINDINA, H. Business model management of low-cost: in a search for impact-factors of performance (case of AirAsia group airlines). Marketing and Management of Innovations [online]. 2020, 2, p. 354-367 [accessed 2020-07-08]. ISSN 2218-4511, eISSN 2227-6718. Available from: http://doi.org/10.21272/ mmi.2020.2-26

[13] European Commission and U. S. Transatlantic Airline Alliances. Competitive issues and regulatory approaches. 2010.

[14] Air transport liberalization and the economic development of the countries - ICAO Assembly, 39th session [online] [accessed 2020-04-23]. 2016. Available from: https://www.icao.int/Meetings/a39/Documents/WP/wp_189_ en.pdf

[15] OUM, T. H., ZHANG, A., FU, X. Air transport liberalization and its impacts on airline competition and air passenger traffic. Transportation Journal [online]. 2010. 49(4), p. 371-390 [accessed 2020-04-15]. ISSN 0041-1612. Available from: https://doi.org/10.2307/40904912

[16] CHAOUK, M., PAGLIARI, R., MOXON, R. The impact of national macro-environment exogenous variables on airport efficiency. Journal of Air Transport Management [online]. 2020, 82, 101740 [accessed 2020-04-23]. ISSN 0969-6997. Available from: https://doi.org/10.1016/j.jairtraman.2019.101740

[17] GILLEN, D., HARRIS, R., OUM, T. H. Measuring the economic effects of bilateral liberalization air transport. Transportation Research Part E: Logistics and Transportation Review [online]. 2002, 38(3-4), p. 155-174 [accessed 2020-05-18]. ISSN 1366-5545. Available from: https://doi.org/10.1016/S1366-5545(02)00003-0

[18] HEIETS, I. The impact of air service agreement liberalization: the case of Ukraine. In: 11th International Conference Modern Problems of Global Processes in the World Economy: proceedings. 2017. ISBN 50-4258-364-0, p. $16-17$

[19] STOPKA, O., BARTUSKA, L., CABAN, J., KAPUSTINA, L. M. Proposal of the functional system for the airline companies financial situation assessment. Communications - Scientific Letters of the University of Zilina [online]. 2019, 21(1), p. 3-8 [accessed 2020-05-18]. ISSN 1335-4205, eISSN 2585-7878 Available from: https://doi.org/10.26552/com.C.2019.1.3-8 
[20] Impact of international air service liberalisation on Chile [online] [accessed 2020-05-25]. Available from: https://www.iata.org/en/iata-repository/publications/economic-reports/chile-benefits-from-furtherliberalization/

[21] Council Regulation (EC) No 411/2004 of 26 February 2004 repealing Regulation (EEC) No 3975/87 and amending Regulations (EEC) No 3976/87 and (EC) No 1/2003, in connection with air transport between the community and third countries (text with EEA relevance) [online]. [accessed 2020-05-03]. Available from: https://eur-lex. europa.eu/legal-content/en/TXT/?uri=CELEX:32004R0411

[22] GASPARI, F. The EU air transport liberalization and re-regulation. International and Comparative Law Review [online]. 2011, 11(2), p. 7-42 [accessed 2020-05-06]. ISSN 2464-6601. Available from: https://doi.org/10.1515/iclr2016-0102

[23] OLESHKO, T., HEIETS, I., PAVLIUK, Y. Characteristics and analysis of development of low-cost airlines in Ukraine. Problems of Systemic Approach in the Economy [online]. 2018, 6(68), p. 153-158. ISSN 2520-2200 [accessed 2020-04-26]. Available from: https://doi.org/10.32782/2520-2200/2018-6-24

[24] Transport and Communications of Ukraine 2012 (in Ukrainian) [online] [accessed 2019-12-11]. Available from: http://www.ukrstat.gov.ua/druk/publicat/Arhiv_u/08/Arch_tr_zb.htm

[25] Transport and Communications of Ukraine 2018 [online] [accessed 2019-12-11]. Available(in Ukrainian). from: http://www.ukrstat.gov.ua/druk/publicat/kat_u/2019/zb/08/zb_tr2018pdf.pdf

[26] State enterprise of air traffic services of Ukraine „Ukraerorukh“ (in Ukrainian) [online] [accessed 2019-12-25]. Available from: https:///uksatse.ua/index.php?s=7fafa5d747ed52968 $70 \mathrm{f} 4 \mathrm{e} 285 \mathrm{~d} 3 \mathrm{e} 17 \mathrm{df} \& \mathrm{act}=$ Part\&CODE $=247 \& \mathrm{id}=450$

[27] OVSAK, O. P., LISKOVYCH, N. Y. Macroeconomic aspects of the impact of air transport development on the economy of Ukraine (in Ukrainian). Black Sea Economic Studies [online]. 2019, 48, p. 133-141 [accessed 202005-03]. ISNN 2524-0897, eISSN 2524-0900. Available from: https://doi.org/10.32843/bses.48-22

[28] KYRYLENKO, O., RIAZANOVSKA, V. NOVAK, V. Strategic airline alliances as a special form of company integration. Baltic Journal of Economic Studies [online]. 2019, 5(1), p. 75-80 [accessed 2020-02-12]. ISSN 2256-0742, eISSN 2256-0963. Available from: https://doi.org/10.30525/2256-0742/2019-5-1-75-80

[29] OLESHKO, T., HEIETS, I. Perspectives of the air transportation market in Ukraine. Aviation [online]. 2018, 22(1), p. 1-5 [accessed 2020-05-24]. ISSN 1648-7788, eISSN 1822-4180. Available from: https://doi.org/10.3846/ aviation.2018.1855

[30] The volume of air navigation services provided to UkSATSE in 2019 increased by 11,5\% / Obsyah nadanykh Ukraerorukhom aeronavihatsiynykh posluh u 2019 rotsi zbil'shyvsya na $11,5 \%$. (in Ukrainian) [online] [accessed 2020-01-06]. Available from: http://uksatse.ua/index. php?s=203f51197ddfa2715bb51336e9de5350\&act=Part\&CODE=247\&id=512

[31] On-line information on key performance indicators of the aviation industry for January 2020 / Operatyvna informatsiya shchodo osnovnykh pokaznykiv diyalnosti aviatsiynoyi haluzi za sichen 2020 roku (in Ukrainian) [online] [accessed 2020-02-16]. Available from: https://avia.gov.ua/pro-nas/statistika/operativna-informatsiya/.

[32] OVSAK, O. P, LISKOVICH, N. Y., NAZARENKO, O. P. Ukraine on the path of aviation liberalization (in Ukrainian). Market Infrastructure [online]. 2020, 40, p. 3-13 [accessed 2020-05-18]. eISNN 2519-2868. Available from: https://doi.org/10.32843/infrastruct40-1

[33] MATSENKO, O. M., HEYETS, I. O., MYRONOVA, Y. V., SKRYPKA, Y. O. Strategic directions of airspace liberalization between Ukraine and the EU / Stratehichni napryamy liberalizatsiyi povitryanoho prostoru mizh Ukrayinoyu ta YES (in Ukrainian). The Mechanism of Economic Regulation / Mekhanizm rehulyuvannya ekonomiky [online]. 2018, 3, p. 66-78 [accessed 2019-12-12]. ISSN 1726-8699. Available from: https://doi. org/10.21272/mer.2018.81.06

[34] Information on the decisions taken by the Commission to consider the rights to operate the routes / Informatsiya shchodo pryynyatykh rishen Komisiyi z roz.hlyadu pytan shchodo prav na ekspluatatsiyu povitryanykh liniy (in Ukrainian) [online] [accessed 2020-01-17]. Available from: https://avia.gov.ua/informatsiya-shhodo-prijnyatihrishen-komisiyi-z-rozglyadu-pitan-shhodo-prav-na-ekspluatatsiyu-povitryanih-linij-14/

[35] COOPER, A., SMITH, P. The Economic catalytic effects of air transport in Europe. Final report. Oxford Economic Forecasting, EEC/SEE/2005/004 [online] [accessed 2020-07-12]. 2002. Available from: https://www. eurocontrol.int/eec/public/standard_page/DOC_Report_2005_025.html

[36] MSITS 2010. Manual on statistics of international trade in services 2010 [online] [accessed 2020-11-23]. Available from: unstats.un.org/unsd/tradeserv/TFSITS/msits2010/M86\%20rev1-white\%20cover.pdf

[37] Air transport services - World Trade Organization [online] [accessed 2020-11-23]. Available from: https://www. wto.org/english/tratop_e/serv_e/transport_e/transport_air_e.htm\#review1

[38] Statistics in respect of the carriage of passengers, freight and mail by air [online] [accessed 2020-05-26]. Available from: https://eur-lex.europa.eu/legal-content/EN/TXT/?qid=1589662698652\&uri=LEGISSUM:124059

[39] Ukraine's international trade in goods and services in 2016. Statistical collection (in Ukrainian) [online] 
[accessed 2019-12-03]. Available from: http://www.ukrstat.gov.ua/druk/publicat/Arhiv_u/10/Arch_ztp_zb.htm

[40] GDP of Ukraine - International monetary fund [online]. Available from: https://www.imf.org/en/Countries/ UKR\#whatsnew

[41] Dynamics of international trade in services by types (in Ukrainian) [online] [accessed 2020-05-29]. Available from: http://www.ukrstat.gov.ua/operativ/operativ2008/zd/dseip/dseip2007_u.htm 